\title{
The frequency of practice of the Catholic social teaching and Sta. Teresa college core values: Development of Teresian core values assessment scale
}

\author{
Rosales, Renniel Jayson Jacinto $\$ \\ Senior High School Department, Sta Teresa College, Batangas, Philippines \\ College of Liberal Arts, Theology and Religious Education Department, De La Salle University - Manila, \\ Philippines (rennieljaysonrosales@gmail.com)
}

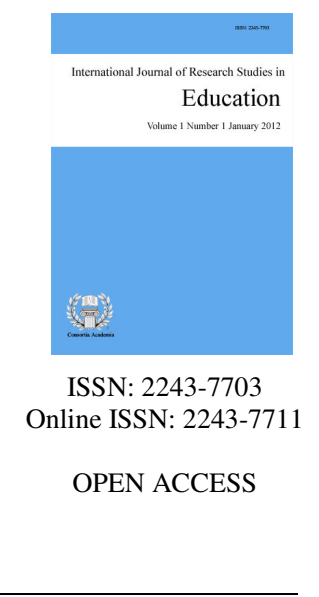

\section{Abstract}

This study aimed to know the practice of Catholic Social Teaching through the core values of concern, responsibility, and service of the faculty members of Sta. Teresa College. Initially, the study aimed to appropriate the Catholic Social Teaching to the Teresian Core Values, which led to the development of an instrument that assessed the extent of the practice of the Teresian Core Values of the faculty members of Sta. Teresa College. The study gave new definitions to each of the Teresian Core Values based on the Catholic Social Teaching and the institution's culture and practice. 72 teachers from different departments of the institution were determined by Slovin's formula to be the respondents of the study. The newly developed Teresian Core Values Assessment Scale (TCVAS) was used to determine the extent of the practice of the respondents. Results have shown that there is no significant difference in the extent of the practice of the respondents when grouped according to profile variables. The extent of the practice of the respondents was determined to be of "Great Extent."

Keywords: core values; Catholic social teaching; education; assessment scale; practice 


\section{The frequency of practice of the Catholic social teaching and Sta. Teresa college core values: Development of Teresian core values assessment scale}

\section{Introduction}

The Catholic Social Teaching of the Church, as a priced treasure on Catholics doctrines, has a valuable contribution to the growth and unity of humanity. It is the best-kept secret of the Church as to how others exclaim it. From the writings of Pope Leo XIII up to Francis, the Church shed light on what we, as Catholics, should do to involve ourselves in the society. From this social teaching of the Church, as CBCP states, it emerges a moral and spiritual vision of the human person and the society. This teaching challenges the imbalances of society and the attitudes of individuals. The view of the Church on the social issues faced by humanity is a clear sign of mission to put into action the message of her teachings. The observation of the Church on different social issues led her to discern and reflect on the values degraded by humanity's fault. Since discernment and reflection will not suffice the urgency of the Church's action, she gave judgments by calling humanity to change his ways for the betterment of all. Through the course of history, the See-Judge-Act scheme of the Church continuously views the reality in our society. It is a part of her mission to evangelize and to save souls.

Since the Church faces many issues in the $21^{\text {st }}$ century, the act of scrutinizing the signs of the times as how Gaudium et Spes initiated it, we are all asked to do something. There could be richness in the social teaching of the Church, but it will remain a best-kept secret if we fail to practice it. The judgments of the Church on the social issues she faced since time immemorial is always timely and applicable. The Church poses this challenge to see the appropriateness of its richness and develop a way of animating it in our life. As a challenge, she draws us to a conclusion of reflecting in our day to day experience and become socially aware of our actions as bases of our judgment to know how well we practiced such teaching. Even if the Church teaches through the pulpit, laities have their role of starting the change in their own home - parents to their children, government officials to their constituents, and teachers to their students. The Vatican II (Flannery, 1984) established a concrete role of the parents to educate their children but need help from the society where the Church looks at education as her duty of proclaiming the way of salvation to all men to attain the fullness of life. The imperative role of Catholic education now enters into the scenario where the teaching of these social doctrines is by far the essential part of Christian living education. Therefore, the role of the teachers is not just to teach students about Catholic Social Teaching but also to practice it to be an exemplar for the next generations.

As part of the Unified Schools of the Archdiocese of Lipa, Sta. Teresa College upholds the Catholic Church's teachings and teaches them to all stakeholders to the best of her capacity. The vision of being a Christ-centered learning community that evangelizes the whole person to become leaders of the society and mission to develop competent and upright individuals in the service of the Catholic Church lead Sta. Teresa College to become a herald of the Church's social teaching. Every activity, program, and lesson are intertwining with the vision and mission of the school, intending to make them part of every student's life. Sta. Teresa College encourages both teachers and students to uphold the core values - concern, responsibility, and service. The Archdiocese's goal, according to Archbishop Garcera (2019), is to ensure that Catholic schools help and not hinder students and educators alike to encounter Jesus, the Light, and let them be in a continuing journey to the light. These core values shape the hearts and minds of both teachers and students in pursuing the vision and mission of the school. As exemplars for the students, the school expects that the teachers will be the ones to practice the core values more often than the students will. Since teachers are in charge of facilitating learning, their knowledge, together with the practice of the core values, should be as close as how the school envisions it. 


\section{Literature review}

\subsection{Catholic social teaching}

The Compendium of the Catechism of the Catholic Church (2005) defines the Catholic Social Teaching or Social Doctrine as the development of the Gospel truth on human dignity and its social dimension that offers principles for reflection, criteria for judgment, and norms for actions. Moreover, the Catholic Bishops' Conference of the Philippines (CBCP) (2008) states that it is also a reflection's result of the complex realities that, according to Cruz (2014), formulates from reasons and ethics in connection with Christian faith and morals.

As part of the magisterium of the Church, Social Teaching offers guidelines on how to live the Gospel of Jesus. The Church fits into the situation of the world by immersing herself into the social issues through an in-depth reflection and judging the reality faced by humanity toward actual teaching and plan to humanize all dehumanization brought by the situation. YOUCAT (2010) mentions that human dignity is an essential nature of man; that is why the Church has the commitment to justice guided by a love that emulates from the love of Jesus for humankind.

Furthermore, CBCP (2008) also emphasized that the basis of the social teaching is the intrinsic dignity of the human person together with human solidarity from which the themes originate. The seven themes of the Catholic Social Teaching are (1) life and dignity of the human person, (2) call to family, community, and participation, (3) rights and responsibilities, (4) option for the poor and vulnerable, (5) the dignity of work and the rights of workers, (6) solidarity, and (7) care for God's creation.

Life and dignity of the human person - The Church, through the incarnation of Christ, cares for every human individual - as how John Paul II (1995) described it, the Church's very heart must necessarily feel every threat to human dignity and life. There is an inescapable duty in every individual to make ourselves a neighbor of everyone by any circumstance that we might encounter. The Pontifical Council for Justice and Peace (2004) states that the laity have an essential task to prioritize the service to human persons rooted from the conversion of hearts to treat everyone as brothers and sisters. The importance of life and dignity is focusing on how a person lives and how he interacts with other people with equality and respect. Pope John Paul II (1991) explained that the dignity of the human person does not come from the work they do but from the persons as who they are, notwithstanding their social status in life. The message in Gaudium et Spes (Flannery, 1984) for the care for life and dignity of the human person has an invaluable effect not only to one's self but also to the society as a whole.

Call to family, community, and participation - Himes (2013) states that the Catholic Social Teaching envisions family as the original human society and the foundation of all social groups, this also includes state as a great social institution. Pope John XXIII (1963) looks at the family as the first and essential cell of human society because of its characteristic as the building block of society. John Paul II (2005) added that a Christian family places itself in service to humanity and the world in forming a Church of love that will advance human. Forming persons in love is also a vital role of the family to extend the relationship not only within the family but also to other communities through concern, sense of justice, and its consciousness of the responsibility to the society. Pope Francis (2015) reiterates that the community networks are the ones to resolve the social problems as one community, not as the sum of individual efforts. The community and participation, as Pope Francis (2019) describes it is an important part to remember since responsible citizenship is a virtue, and participation in every political issue is a moral obligation.

Rights and responsibilities - The performance of the rights and responsibilities of the human person leads to the promotion of human dignity. The rights and responsibilities that accord to one should be present to others as well. When one practices his rights and responsibilities, others should also be benefitting rights and responsibilities. Pope John XXIII (1961) purposely identifies the duty of the state to protect the rights of all people, especially the weak, women, and children. The rights and responsibilities of the human person pin down 
to the principle of the common good, which speaks of the relatedness of every aspect of social life in attaining the its meaning from dignity, unity, and equality of people (Pontifical Council for Justice and Peace, 2004). This common good does not only speak of what one should receive but also includes what one should give to other people.

John XXIII (1963) explicitly defines human rights and responsibilities (duties). On one hand, human's right includes the right to live, the right to bodily integrity and the necessary means for the development of life. Every individual has the right to have the means of livelihood without being discriminated against the appearance of social status. On the other hand, the responsibilities (duties) vested on every individual corresponds to what an individual receives. The primary duty of man is to respect the rights of others. Hence, the common good, in terms of our rights and responsibilities, involves all of us as members of society. No one is exempted from cooperating according to each one's possibilities and capabilities in attaining it and developing it (Pontifical Council for Justice and Peace, 2004).

Option for the poor and vulnerable - The importance of the poor is a vital part of the Church's teachings. The love for the poor is part of her constant tradition of enabling those who are lowly as how Jesus preached the Beatitudes. This preference is incompatible with selfishness and love for riches. The poor and vulnerable are those affected not only materially but also spiritually and socially. The value of being pro-poor, according to CBCP (1992), has an evangelical basis, which leads us to be more concerned on issues concerning the poor and the lowly, the vulnerable, including tribal Filipinos and marginalized sectors. For Pope Francis (2014), preferential option for the poor and vulnerable is not only helping the poor and vulnerable materially. This preference aims to fight against the structural causes of poverty and inequality. This is a fight against the destructive effects of wealth because the poor are the victims.

Moreover, Himes (2013) looks at the preferential option for the poor and vulnerable as a vision, a concern, and a call. It is a vision where one should look outside of himself, to put one's place in a poor person - to choose (option) in seeing first (preference) as to how poor people see it. It is also a moral concern where one should look first on the needs of the poor and vulnerable before those who are better off. The poor affect the moral priorities of every person. Lastly, the preferential option for the poor and vulnerable is a call to empowerment or liberation. This preference entails the rights of the poor to have an active role in the process of achieving common good - empowerment for them, not just giving material help.

The dignity of work and the rights of workers - The dignity of work and rights of workers challenges the faithful to be aware and sensitive to the duty of purposive work and integrity of the workers. John Paul II (1981) gives the importance of work on the existence of the human person that lies in itself as part of one's activity in transforming nature and achieving fulfillment as a human being. Work has a place in every person to have a better condition in life and the best instrument against poverty. It is also an obligation on the part of man. An individual maintains and develops the structure of the human person through work. John Paul II (1981) added the twofold significance of human work: objective and subjective. The objective significance of human work speaks of the exercise of dominion over the earth. In contrast, the subjective significance of human work speaks of the ability to be dynamic and capable of performing a variety of actions in the process of work.

Solidarity - DOCAT (2016) defines the principle of solidarity implies the expression to the social dimension of human beings where one lives with others showing dependency and the need for the conversation to develop one's self. Solidarity, as how the Catechism of the Catholic Church (1994) discusses it, has two complementary aspects: a social principle and a moral virtue. As a social principle, solidarity speaks of friendship and social charity, where one learns to negotiate on the distribution of goods and remunerate work instead of having a conflict over it. In the same manner, solidarity is also a moral virtue that goes beyond material goods to the spiritual goods of the faith. In the words of Pope John Paul II (1987), solidarity is the perseverance of one to commit for the common good because we are responsible for all. Furthermore, Pope Benedict XVI (2009) explains that the common good is a basis of solidarity where one should always seek the good of the other and to 
fulfill the requirement of justice and charity.

Care for God's creation - The care for God's creation is a manifestation of the relationship of man towards the environment and, in turn, towards God Himself. Though the destruction of creation falls in humanity's fault due to anthropocentric ideas, the moral nature of the ecological crisis points out to the responsibility of all people for preserving the integrity of creation (Himes, 2013). This preservation of creation leads to a dynamic understanding of the importance of the environment where humans reside (Baring, del Castillo, \& Guanzon, 2020). There is an urgent call, according to Pope Francis (2015), for the protection of the common home, including the human family, in cleaning the earth for the next generation by developing our common home. Furthermore, Pope Benedict XVI (2009) explains that humans must preserve and protect the environment, for it is the source of all goods needed to live with dignity and must recognize the grave duty to let the future generations live on earth where they can still inhabit and cultivate it. Pope Francis (2015) emphasized that the care for God's creation is a protection not only for the environment but also for the entire human race. As stewards, not to misuse the environmental resources. We are obliged to be stewards and accountable for what we have done to God's creation (CBCP, 1992).

\subsection{Sta. Teresa College and its core values}

Sta. Teresa College, formerly known as St. Theresa's Academy, is a Roman Catholic educational institution that caters to the needs of the Archdiocese of Lipa since the 1920s. Since then, STC envisions to be a leading Catholic educational institution that produces academically exemplary, spiritually alive, and socially responsive individuals. The mission is to be faithful with its vision and the teachings of St. Teresa of Avila, the school provides quality educational programs and value-laden activities to develop evangelized individuals in the service of the Church and society (Sta. Teresa College, 2010). Recently, STC reorganized, and the vision-mission of the institution transforms into the vision of being a Christ-centered learning community that evangelizes the whole person to become leaders of the society and mission to develop competent and upright individuals in the service of the Catholic Church.

By looking at the former and present vision-mission of the school, the core values of concern, responsibility, and service are present and continue to be the school's spirit. Being part of the Unified Schools of the Archdiocese of Lipa, STC also adopts the two core values of Faith and Integrity in unity with all the member-schools of USAL. Moreover, STC recognizes the roles and concerns everyone played for her development with a sense of reverence, reminding the responsibility everybody must share to be of service to all those who need one. As a guiding principle and goal, STC school objectives aim to have graduates to be practicing Christians who believe and practices the Christian virtues of honesty, courage, responsibility, justice, cooperation, love, and peace while recognizing their dignity as well as with the others. In the same manner, she also aims to form useful citizens who are critically aware of and are critically involved in the social, economic, and political affairs of the community to which they belong. Graduates are also expected to be responsive to the needs of their neighbors and render meaningful service to those who need assistance while treating the less fortunate with justice and love. (Sta. Teresa College, 2010).

In the study of Jollands, Akroyd, and Sawabe (2015), core values are management controls enrolled by senior managers in identifying a shared understanding of organizational purpose where actors (employees/stakeholders) are expected to search and perform. These core values are designed, according to Ouchi (1979), in guiding the actors (teachers) of what is expected by the institution due to the inability to measure the inputs, processes, and outputs perfectly. Each organization has guiding core values to help all stakeholders perform a shared value and understanding of the organization. All organizations and institutions are putting their core values at the heart of their programs, activities, and performances. Educational institutions, which form not only the educators but the students as well, also give significant importance to the core values they live and perform. 
The core values of concern, responsibility, and service play an essential role in the life not only of the students but also of the teachers. These core values have a basis on the Gospel values inculcated to the culture of both students and teachers. These values are understood in a Teresian way, a deeper understanding and practice executed since then. The value of concern is not just about being concerned with others but has a more profound value of being involved with others. Responsibility speaks of having an initiative of doing things while becoming responsible for the outcome of such action. The value of service extends not only within the school but also to the Church and society. When it comes to the practice of the core values, long-tenured teachers practice the core values evidently while the new teachers seem to be manifesting the core values with many loopholes. The values of concern, responsibility, and service for teachers should not be bound to the working hours. They should be reflected even outside the school with a profound manifestation of responsibility in serving others $(\mathrm{O}$. Villanueva, 2020).

Moreover, the core values are also known as the practice centered on the life of Christ, Catholic, and has a Filipino context integrated into concern, responsibility, and service. Being Filipino Catholics, we grew up having concerns with other people in and outside of the school. The value of responsibility the teachers are performing includes not only the typical way of doing things but religiously performing the task depending on the office held and to the students under our care. The value of service speaks of the activities extended to the Church and the community, especially the less fortunate people, including the victims of calamities. The trend of modern society affects the way teachers perform the core values but are still doing it differently but fitted the signs of the times. The length of service also affects the practice of the core values since older teachers in the institution manifest more than the newer ones (H. Villanueva, 2020).

Furthermore, the Teresian Core Values are the guide for Sta. Teresa College students and employees. The value of concern revolves around our care for those around us by correcting the mistakes of others and making them have a good way of life. The value of responsibility focuses on the responsibility as a Catholic, as a teacher/employee, and as a student for the betterment of the community. The value of service revolves around the response to the needs of others, may it be inside or outside of the school. The Teresian Core Values should affect the behavior of every Teresian to society as a whole. These core values manifest a life dedicated "Always for Jesus" and to always put that their words and actions will always be in God's honor and glory (Abante, 2020).

In the practice and perspectives of the students, the study of Buhat, De Castro, and Montibon (2018) entitled "Social influence and attitude towards Teresian Core Values of Grade 12 students in Sta. Teresa College", aimed to measure the relationship between social influence and attitude towards Teresian Core Values based on the practice of the Grade 12 students. They used a self-made questionnaire based on the standard practice of each value. Results have shown that the attitude of the students towards the values of concern, responsibility, and service fell on "Sometimes Observed".

In this study, the researcher seeks to know the practice of Catholic Social Teaching through the core values of concern, responsibility, and service of the faculty members of Sta. Teresa College. Initially, the study aims to develop an instrument that will assess the practice of the Teresian Core Values of the faculty members of Sta. Teresa College. To this aim, the following research questions were addressed:

$>$ How are the Catholic Social Teaching themes appropriated in Sta. Teresa College Core Values?

$>\quad$ How are these values expressed in a meaningful behavioral attribute?

$>\quad$ What is the extent of the practice of the Teresian Core Values of the respondents?

$>$ Is there a significant difference on the practice of the participants when grouped according to profile variables? 


\section{Methodology}

\subsection{Development of the instrument}

Search for content domain - In the search for the content domains, the Catholic Social Teaching was appropriated through its seven themes to the Teresian Core Values. The primary reference considered for the practice of the core values incorporated with Catholic Social Teaching came from the definition gathered from the interviews done to vital personnel of Sta. Teresa College. The past and present vision and mission and philosophy of the institution were also considered. The content domains are:

$>$ Concern - The value of concern sprouts from the internal Christian drive of every Teresian to seek for the good of others by promoting the dignity of the human person, common good, and peace and unity of all.

$>$ Responsibility - The value of responsibility stems from the responsive social identity of every Teresian to respond to the call of others by committing to a responsible and responsive life towards a solidary ecclesial, social, economic, and political transformation.

$>$ Service - The value of service bears witness from the servant-leadership mission of every Teresian to serve the needs of others by living to help the poor and vulnerable and conserve God's creation.

Item writing and review - Based on the literature, 45 items under three factors were constructed, and the verbal frequency scale was used. Five experts from the campus ministry office, guidance office, and administrative body reviewed the items. Out of the 45 items, 4 items were asked to be revised while the rest were accepted (see figure 1).

Development of the try-out form - The instrument used for this study was the newly developed Teresian Core Values Assessment Scale. It contained a 45-item, 6-point Likert type self-report instrument following the existing core values of Sta. Teresa College based on Catholic Social Teaching and practiced culture of the institution. The participants were asked to rate their frequency of practice to each of the statement using a scale from " 6 " as Always to " 1 " as Never.

Test administration - The administration of the assessment scale was done to initially establish the psychometric properties of the Teresian Core Values Assessment Scale. The instrument was administered to a total number of 72 participants through online form. The sampling design was random and done individually from different departments of the institution.

Evaluation of test validity - The validity of the Teresian Core Values Assessment Scale was determined using exploratory factor analysis with Oblimin Rotation (Principal Axis Extraction) was performed using a 3 -factor solution. Factor loading of 0.3 or greater was adopted for the screening of the items. Due to the failure to factor the items into three, the researcher explored the scree plot of the Eigenvalues showing that there is only one factor fitted for all the items. Out of the 45 items, considering all the items into one factor, three items were dropped (C11, R2, and R3). The one-factor loading resulted in the conclusion that all the items go with one another as they are interrelated into one Teresian Spirituality.

Evaluation of test reliability - The reliability of the Teresian Core Values Assessment Scale was determined using the Cronbach's Coefficient Alpha formula. This method examines the internal consistency of the said scale through an analysis of the individual test items. The inventory was administered once to 72 participants who are all teaching personnel at Sta. Teresa College. The measure of internal consistency indicates the extent to which the items of the inventory interrelate and represent similar content. This internal consistency shows that the contents are relatively homogenous. Based on the 42 remaining items in the scale, the Cronbach's Coefficient Alpha was computed for each core value and the inventory as a whole. The Value of Concern got a Cronbach's 
Rosales, R. J. J.

Coefficient Alpha of .880. The Value of Responsibility got a Cronbach's Coefficient Alpha of .866. The Value of Service got a Cronbach's Coefficient Alpha of .883. The whole inventory got a Cronbach's Coefficient Alpha of .949 , which indicates a very high level of internal consistency.

\begin{tabular}{|c|c|c|}
\hline Core Values & Core Values Domain & Inventory \\
\hline Concern & $\begin{array}{l}\text { The value of concern } \\
\text { sprouts from the } \\
\text { internal Christian drive } \\
\text { of every Teresian to } \\
\text { seek for the good of } \\
\text { others by promoting } \\
\text { the dignity of the } \\
\text { human person, } \\
\text { common good, and } \\
\text { peace and unity of all. }\end{array}$ & $\begin{array}{l}\text { 1. I consider others' welfare before myself. } \\
\text { 2. I respect the ideas of others. } \\
\text { 3. I resolve my conflict with others by talking to the one involved. } \\
\text { 4. I prefer to give than to receive. } \\
\text { 5. I plan things that are beneficial to all. } \\
\text { 6. I rejoice with the success of others, even if I fail in the same discipline. } \\
\text { 7. I listen to what others are saying before I speak. } \\
\text { 8. I do things without expecting something in return. } \\
\text { 9. I willingly extend time and effort in doing my task if necessity arises. } \\
\text { 10. I look at the two sides of the story before making any comment. } \\
\text { 11. I favor pro-life campaigns such as anti-abortion and anti-divorce advocacies. } \\
\text { 12. I am fair in treating others. } \\
\text { 13. I see to it that everyone receives/gets an equal opportunity when asked to lead. } \\
\text { 14. I lead by looking after the needs of others to succeed. } \\
\text { 15. I follow the rules and regulations of my institution. }\end{array}$ \\
\hline Responsibility & $\begin{array}{l}\text { The value of } \\
\text { responsibility stems } \\
\text { from the responsive } \\
\text { social identity of every } \\
\text { Teresian to respond to } \\
\text { the call of others by } \\
\text { committing to a } \\
\text { responsible and } \\
\text { responsive life towards } \\
\text { a solidary ecclesial, } \\
\text { social, economic, and } \\
\text { political } \\
\text { transformation. }\end{array}$ & $\begin{array}{l}\text { 1. I do my tasks efficiently. } \\
\text { 2. I serve in our parish. } \\
\text { 3. I attend Sunday and Obligatory Masses regularly. } \\
\text { 4. I do my responsibility to my family. } \\
\text { 5. I am prudent in correcting the mistakes of others. } \\
\text { 6. I support without bias to politicians/candidates. } \\
\text { 7. I support Church advocacies with all my heart. } \\
\text { 8. I look for the owner of something missing that I found, even if no one is around. } \\
\text { 9. I promote Christian values to others when there is a possibility. } \\
\text { 10. I help other people, even if they do not help me. } \\
\text { 11. I support the thoughts/ideas of others as long as it is for the good of all. } \\
\text { 12. I stand responsible for every decision I make, even if it fails. } \\
\text { 13. I embody my rights and responsibility as a citizen. } \\
\text { 14. I cooperate well with others, even if I do not like them. } \\
\text { 15. I respect the personal space/privacy of others. }\end{array}$ \\
\hline Service & $\begin{array}{l}\text { The value of service } \\
\text { bears witness from the } \\
\text { servant-leadership } \\
\text { mission of every } \\
\text { Teresian to serve the } \\
\text { needs of others by } \\
\text { living to help the poor } \\
\text { and vulnerable and } \\
\text { conserve God's } \\
\text { creation. }\end{array}$ & $\begin{array}{l}\text { 1. I pick up trash whenever I encounter one to keep the vicinity clean. } \\
\text { 2. I want my area clean, that is why I clean it by myself regularly. } \\
\text { 3. I reuse/recycle my old stuff, including papers and bags. } \\
\text { 4. I reduce pollution by doing proper waste segregation. } \\
\text { 5. I only buy things that I need, disregarding my wants. } \\
\text { 6. I give my things to others rather than trash them. } \\
\text { 7. I help people in need without any bias or other motives. } \\
\text { 8. I share whatever thing I have to my colleagues. } \\
\text { 9. I give any possible support to charity outside our institution. } \\
\text { 10. I help/give with humility and love for others. } \\
\text { 11. I give way to the sick, old, pregnant, or differently-abled person when in a public vehicle } \\
\text { or falling in line at a store/restaurant. } \\
\text { 12. I initiate activities to support those in need. } \\
\text { 13. I offer food to others, even if it is few/limited. } \\
\text { 14. I visit a sick family member/ friend/ colleague/ student/ classmate. } \\
\text { 15. I give/donate to sacrifice collection. }\end{array}$ \\
\hline
\end{tabular}

Figure 1. Teresian core values assessment scale inventory/construct

Development of the final form - In the final form, 42 items were accepted in the process. There is one factor extracted using exploratory factor analysis that combines the three different values. Dropping items C11, R2, and R3. The Teresian Core Values Assessment Scale was finalized with a 42-item inventory to assess the extent of practice of Teresian Core Values of the teaching personnel of STC according to the practice and culture of the institution. The participants will be instructed to indicate their frequency of practice for each of the items in the inventory using a scale from " 6 " as Always to " 1 " as Never.

In scoring the Teresian Core Values Assessment Scale subscale and overall, one will simply add the ratings 
for each item per cluster: Concern, Responsibility, and Service. In interpreting the raw scores per subscale and overall, the following arbitrary scaling was computed:

$\begin{array}{ll}5.50 \text { and above } & \text { Always }-(100 \% \text { of the time if there is a chance }) \\ 4.50-5.49 & \text { Frequently }-(80 \% \text { of the time if there is a chance }) \\ 3.50-4.49 & \text { Often }-(60 \% \text { of the time if there is a chance }) \\ 2.50-3.49 & \text { Sometimes }-(40 \% \text { of the time if there is a chance }) \\ 1.50-2.49 & \text { Rarely }-(20 \% \text { of the time if there is a chance }) \\ 1.49 \text { and below } & \text { Never }-(0 \% \text { of the time if there is a chance })\end{array}$

In interpreting the raw scores to get the extent of practice of the Teresian Core Values, the following arbitrary scaling was computed:
4.76 and above
$3.51-4.75$
Very Great Extent
$2.26-3.50$
Great Extent
2.25 and below
Less Extent
Least Extent

It is evident that the results of this study that the Teresian Core Values Assessment Scale is a valid and reliable instrument. Statistically accepted items of this scale manifest the vision (thought) and mission (practice) that reflect the Teresian Core Values of Concern, Responsibility, and Service.

\subsection{Participants}

The study had a total of 72 teaching personnel of Sta. Teresa College as the participants. The sample size was based on Slovin's formula. A simple random sampling was employed. Participants came from the four departments of Sta. Teresa College, namely: Grade School, Junior High School, Senior High School, and College.

\subsection{Data analysis}

To address the quantitative part of the research questions, different statistical analyses were used. Frequencies of each profile variable were calculated. One-way ANOVA and independent samples t-test were used to know the difference on the assessments of the participants according to their profile variables.

\section{Results}

\subsection{Demographic profile}

The participants were composed of $80.6 \%$ female. $43.1 \%$ of the participants were serving in the school for five years and below, 9.7\% were serving for six to 10 years, the remaining participants were serving for 10 years and beyond. In the departments' participation, the participants were composed of $22.2 \%$ from the grade school, $36.1 \%$ from the junior high school, $19.4 \%$ from the senior high school, and $22.2 \%$ from the college.

\subsection{Extent of practice}

Table 1 shows the frequency of practice of practice of the Teresian Core Value of Concern interpreted as "Frequently" with an overall weighted mean of 5.36. The practice, which has the highest weighted mean, was the promotion and following the rules and regulations of the institution having a weighted mean of 5.60 with a verbal interpretation of "Always". On the contrary, the practice, which has the lowest weighted mean, was the consideration of others' welfare before one's self having a weighted value of 5.04 with a verbal interpretation of "Frequently".

The table shows that the participants promote and follow the rules and regulations of the institution since 
Rosales, R. J. J.

they are bound to be part of it. On the other hand, it also shows that they have a lower consideration in the welfare of others.

\section{Table 1}

Frequency of practice of the value of concern

\begin{tabular}{|c|c|c|}
\hline Items & $\begin{array}{l}\text { Weighted } \\
\text { Mean }\end{array}$ & $\begin{array}{c}\text { Verbal } \\
\text { Interpretation }\end{array}$ \\
\hline 1. I consider others' welfare before myself. & 5.04 & Frequently \\
\hline 2. I respect the ideas of others. & 5.43 & Frequently \\
\hline 3. I resolve my conflict with others by talking to the one involved. & 5.10 & Frequently \\
\hline 4. I prefer to give than to receive. & 5.25 & Frequently \\
\hline 5. I plan things that are beneficial to all. & 5.25 & Frequently \\
\hline 6. I rejoice with the success of others, even if I fail in the same discipline. & 5.42 & Frequently \\
\hline 7. I listen to what others are saying before I speak. & 5.38 & Frequently \\
\hline 8. I do things without expecting something in return. & 5.42 & Frequently \\
\hline 9. I willingly extend time and effort in doing my task if necessity arises. & 5.50 & Always \\
\hline 10. I look at the two sides of the story before making any comment. & 5.31 & Frequently \\
\hline 11. I am fair in treating others. & 5.38 & Frequently \\
\hline $\begin{array}{l}\text { 12. I see to it that everyone receives/gets an equal opportunity when asked } \\
\text { to lead. }\end{array}$ & 5.43 & Frequently \\
\hline 13. I lead by looking after the needs of others to succeed. & 5.31 & Frequently \\
\hline 14. I promote and follow the rules and regulations of my institution. & 5.60 & Always \\
\hline Overall Weighted Mean & 5.36 & Frequently \\
\hline
\end{tabular}

Table 2

Frequency of practice of the value of responsibility

\begin{tabular}{|c|c|c|}
\hline Items & $\begin{array}{c}\text { Weighted } \\
\text { Mean }\end{array}$ & $\begin{array}{c}\text { Verbal } \\
\text { Interpretation }\end{array}$ \\
\hline 1. I do my tasks effectively and efficiently. & 5.42 & Frequently \\
\hline 2. I do my responsibility to my family. & 5.69 & Always \\
\hline 3. I am prudent in correcting the mistakes of others. & 4.79 & Frequently \\
\hline 4. I support without bias to politicians/candidates. & 4.83 & Frequently \\
\hline 5. I support Church advocacies with all my heart. & 5.42 & Frequently \\
\hline $\begin{array}{l}\text { 6. I look for the owner of something missing that I found, even if no one } \\
\text { is around. }\end{array}$ & 5.58 & Always \\
\hline $\begin{array}{l}\text { 7. I promote and live the Gospel values to others when there is a } \\
\text { possibility. }\end{array}$ & 5.44 & Frequently \\
\hline 8. I help other people, even if they do not help me. & 5.28 & Frequently \\
\hline 9. I support the thoughts/ideas of others as long as it is for the good of all. & 5.61 & Always \\
\hline 10. I stand responsible for every decision I make, even if it fails. & 5.60 & Always \\
\hline 11. I embody my rights and responsibility as a citizen. & 5.49 & Frequently \\
\hline 12. I cooperate well with others, even if I do not like them. & 5.26 & Frequently \\
\hline 13. I respect the personal space/privacy of others. & 5.54 & Always \\
\hline Overall Weighted Mean & 5.30 & Frequently \\
\hline
\end{tabular}

Table 2 shows the frequency of practice of practice of the Teresian Core Value of Responsibility interpreted as "Frequently" with an overall weighted mean of 5.30. The practice, which has the highest weighted mean, was doing the responsibility to the family having a weighted mean of 5.69 with a verbal interpretation of "Always". On the contrary, the practice, which has the lowest weighted mean, was being prudent in correcting the mistakes of others having a weighted value of 4.79 with a verbal interpretation of "Frequently".

The table also shows that the participants are more responsible when it comes to their family since family is the foundation of one's life. On the other hand, it also shows a lack of responsibility when it comes to being prudent in correcting others, which can be can implied that the participants are straightforward in correcting others. 
Table 3

Frequency of practice of the value of service

\begin{tabular}{|c|c|c|}
\hline Items & $\begin{array}{l}\text { Weighted } \\
\text { Mean }\end{array}$ & $\begin{array}{c}\text { Verbal } \\
\text { Interpretation }\end{array}$ \\
\hline 1. I pick up trash whenever I encounter one to keep the vicinity clean. & 4.96 & Frequently \\
\hline 2. I want my area clean that is why I clean it by myself regularly. & 5.43 & Frequently \\
\hline 3. I reuse/recycle my old stuff, including papers and bags. & 5.21 & Frequently \\
\hline 4. I reduce pollution by doing proper waste segregation. & 5.01 & Frequently \\
\hline 5. I only buy things that I need, disregarding my wants. & 4.97 & Frequently \\
\hline 6. I give my things to others rather than trash them. & 5.07 & Frequently \\
\hline 7. I help people in need without any bias or other motives. & 5.44 & Frequently \\
\hline 8. I share whatever thing I have to my colleagues. & 5.24 & Frequently \\
\hline 9. I give any possible support to charity outside our institution. & 4.93 & Frequently \\
\hline 10. I help/give with humility and love for others. & 5.43 & Frequently \\
\hline $\begin{array}{l}\text { 11. I give way to the sick, old, pregnant, or differently abled person when } \\
\text { in a public vehicle or falling in line at a store/restaurant. }\end{array}$ & 5.36 & Frequently \\
\hline 12. I initiate activities to support those in need. & 4.53 & Frequently \\
\hline 13. I offer food to others, even if it is few/limited. & 5.08 & Frequently \\
\hline 14. I visit a sick family member/ friend/ colleague/ student/ classmate. & 4.65 & Frequently \\
\hline 15. I give/donate to sacrifice collection. & 4.78 & Frequently \\
\hline Overall Weighted Mean & 5.07 & Frequently \\
\hline
\end{tabular}

Table 3 shows the frequency of practice of practice of the Teresian Core Value of Service interpreted as "Frequently" with an overall weighted mean of 5.07. The practice, which has the highest weighted mean, was helping people in need without any bias or other motives having a weighted mean of 5.44 with a verbal interpretation of "Frequently".

On the contrary, the practice, which has the lowest weighted mean, was the initiation of activities for those in needs having a weighted value of 4.53 with a verbal interpretation of "Frequently". The table shows that the participants help those people in need without any bias or other motives since it has been a culture of the institution to help. On the other hand, it also shows that they have a lower consideration in initiating activities to help those in needs since the works they have as teachers already preoccupy them.

Table 4

Extent of practice of the core values

\begin{tabular}{lcc}
\hline \multicolumn{1}{c}{ Subscale } & $\begin{array}{c}\text { Weighted } \\
\text { Mean }\end{array}$ & $\begin{array}{c}\text { Verbal } \\
\text { Interpretation }\end{array}$ \\
\hline Value of Concern & 5.36 & Very Great Extent \\
Value of Responsibility & 5.30 & Very Great Extent \\
Value of Service & 5.07 & Very Great Extent \\
\hline Overall Weighted Mean (Overall Practice of Teresian Core Values) & 5.24 & Very Great Extent \\
\hline
\end{tabular}

Table 4 shows the extent of practice of the Teresian Core Values of the participants where the overall weighted mean which represents the overall practice of the Teresian Core Values is 5.24 which can be interpreted as "Very Great Extent". All the subscales pertaining to the core values got the same interpretation of "Very Great Extent".

The table shows the weighted mean per subscale showing that the Value of Concern got the highest mean while the Value of Service got the lowest mean. Though they have the same verbal interpretations, it is clear that the Value of Service is far from the two other measured values. 
Rosales, R. J. J.

\subsection{Significant differences}

Table 5

Difference on the practice of the participants when grouped according to biological gender

\begin{tabular}{lcccc}
\hline \multicolumn{1}{c}{ Variables } & Mean & Mean Difference & $p$-value & Verbal Interpretation \\
\hline Female & 5.25 & 0.0168 & .882 & Not Significant \\
Male & 5.23 & & & \\
\hline
\end{tabular}

Table 5 shows the difference on the practice of the Teresian Core Values according to biological gender. It got a computed $p$-value of .882 , which failed to reject the null hypothesis. The result implies that the practice between female and male participants has no significant difference.

Table 6

Difference on the practice of the participants when grouped according to years of service

\begin{tabular}{lccc}
\hline \multicolumn{1}{c}{ Variables } & Mean & $p$-value & Verbal Interpretation \\
\hline $0-5$ Years & 5.27 & .491 & Not Significant \\
$6-10$ Years & 5.23 & & \\
11 Years and above & 5.14 & & \\
\hline
\end{tabular}

Table 6 shows the difference in the practice of the Teresian Core Values according to years of service. It got a computed p-value of 0.491 , which failed to reject the null hypothesis. The result implies that the practice of the participants, which has a year of service from 0-5 years, 6-10 years, and 11 years and above, have no significant difference.

Table 7

Difference on the practice of the participants when grouped according to department

\begin{tabular}{lccc}
\hline \multicolumn{1}{c}{ Variables } & Mean & $p$-value & Verbal Interpretation \\
\hline Grade School Department & 5.16 & .578 & Not Significant \\
Junior High School Department & 5.33 & & \\
Senior High School Department & 5.23 & & \\
College Department & 5.20 & & \\
\hline
\end{tabular}

Table 7 shows the difference on the practice of the Teresian Core Values according to the department of the participants. It got a computed p-value of 0.578 , which failed to reject the null hypothesis. The result implies that the practice of the participants from the grade school department, junior high school department, senior high school department, and college department have no significant difference.

\section{Discussion}

\subsection{How are the Catholic Social Teaching themes appropriated in Sta. Teresa College Core Values?}

In the appropriation of Catholic Social Teaching to the Teresian Core Values, an in-depth study of the culture and practice of the Teresian community was initially done. After knowing the culture of practice, the appropriation of the seven themes of Catholic Social Teaching was done to each of the core values. Since there is no firm and written definition for each core value, definitions were also given.

The themes of life and dignity of the human person, call to family, community and participation, and dignity of works and rights of workers were appropriated to the Teresian Core Value of Concern. Thus, it was defined that the Teresian Core Value of concern sprouts from the internal Christian drive of every Teresian to seek for the good of others by promoting the dignity of the human person, common good, and peace and unity of all. The value of concern was analogized to the sprouting of a plant, having the source of the internal Christian drive and the mission to seek for the good of others by promoting goodness. The value is considered part of the cognitive

70 Consortia Academia Publishing (A partner of Network of Professional Researchers and Educators) 
domain of learning.

The themes of solidarity and rights and responsibilities were appropriated to the Teresian Core Value of Responsibility. Thus, it was defined that the Teresian Core Value of Responsibility stems from the responsive social identity of every Teresian to respond to the call of others by committing to a responsible and responsive life towards a solidary ecclesial, social, economic, and political transformation. The value of responsibility was analogized to the stemming of a plant, having the responsive social identity as its source and the mission to respond to the call of others by committing to a responsible and responsive life towards the community. The value is considered part of the affective domain of learning.

The themes of care for the poor and vulnerable and care for God's creation were appropriated to the Teresian Core Value of Service. Thus, it was defined that the Teresian Core Value of Service bears witness from the servant-leadership mission of every Teresian to serve the needs of others by living to help the poor and vulnerable and conserve God's creation. The value of service was analogized to bearing of a plant, having the source of servant-leadership mission to serve the needs of other by living in communion with God's creation. The value is considered part of the psychomotor domain of learning.

\subsection{How are these values expressed in a meaningful behavioral attribute?}

Results have shown that the practice of the Teresian Core Values of the teaching personnel of Sta. Teresa College is has a high frequency. The value of concern got a weighted mean of 5.36 followed by the value of responsibility with 5.30. The value of service got the lowest mean of 5.07. Though all values were interpreted as "Frequent", focus should be given on how to improve the value of service since all values are interrelated with one another. The results gave implication to the need of the teachers to know and understand more the Teresian Core Values, especially the value of service.

Value of Concern - The practice of the value of concern shows that the teachers promote and follow the rules and regulations of the institution. Results also show that consideration in the welfare of others got the lowest score.

Value of Responsibility - The practice of the value of responsibility shows that the participants are more responsible when it comes to their family but they have a lack of responsibility in being prudent on correcting others.

Value of Service - The practice of the value of service shows that the participants help those people in need without any bias or other motives but they have a lower consideration in initiating activities to help those in needs.

\subsection{What is the extent of the practice of the Teresian Core Values of the participants?}

With a general weighted mean of 5.25, the extent of practice of the Teresian Core Values is interpreted as "Great Extent". The result shows that the practice of the core value is good though there is still a need for programs and activities that might help the teachers to practice more each value consistently.

\subsection{Is there a significant difference in participants' practice in terms of gender, years of service, \& department?}

The results have shown that there is no significant difference on the extent of practice of the Teresian Core Values of the teachers when grouped according to profile variables. The differences on biological gender with a $p$-value of .882 , on years of service with a $p$-value of .491 , and on the department with the $p$-value of .578 all failed to reject the null hypothesis. 


\section{Conclusion}

Based on the findings, the following conclusions were made:

$>$ The Catholic Social Teaching is well-appropriated to the Teresian Core Values since they both have the same goal of being socially aware and sensitive to the needs of others. The Catholic Social Teaching's seven themes gave light to the understanding of the Teresian Core Values of Concern, Responsibility, and Service. Since there is no firm definition of each of the core values. The definition for each value was given to have a solid foundation for every action and a demarcation line between the values.

$>$ The practice of the Teresian Core Values has a high frequency when understood based on the answers of the respondents. Though the value of service got the lowest weighted mean, they all have weighted means close to each other, and it merely shows that the core values practice is interrelated to one another.

$>\quad$ The practice of the Teresian Core Values is of "Great Extent" and shows that the Teresian educators across gender, years of service, and department practices the core values frequently.

$>$ There is no significant difference between the extent of the practice of the respondents when grouped according to profile variables. This may infer that the employees are led to practice the core values in various ways through the activities and the spirit of the institution.

\subsection{Recommendations}

In light of the findings and conclusions, the following recommendations were given:

> The established definitions of the Teresian Core Values appropriated with Catholic Social Teaching may be used to guide the institution in viewing its core values. This may serve as a firm definition for each value in initiating activities and programs for development.

$>\quad$ The results of the extent of the practice of the Teresian Core Values may be used by the Campus Ministry Office to develop socio-spiritual programs and activities that may improve the practice of the core values. The result may also be used to compare the practice of the students and teachers.

> The newly developed Teresian Core Values Assessment Scale (TCVAS) may be used for future reference in assessing the practice of the employees. Through this scale, there would be a standardized assessment scale for the practice of the core values.

D Future researchers may appropriate the TCVAS to other stakeholders by improving or revising the inventory of the scale. The parents/guardians, students, and non-teaching personnel, as part of the Teresian community, must also be assessed to have a full-scale program that will benefit all stakeholders.

\section{References}

Abante, M. (2020, March 10). Interview by R. J. J. Rosales [In-person].

Akroyd, C., Jollands, S., \& Sawabe, N. (2015). Core values as a management control in the construction of "sustainable development". Qualitative Research in Accounting \& Management, 12(2), 127-152. https://doi.org/10.1108/QRAM-04-2015-0040

Baring, R., del Castillo, F., \& Guanzon, M. (2020). Climate change and service learning in the light of Laudato Si: Reviewing educator's perceptions. International Journal of Climate Change: Impacts and Responses, 12(1). https://doi.org/10.18848/1835-7156/CGP/v12i01/1-12 
Catholic social teaching and Sta. Teresa core values: Development of Teresian core values assessment scale

Buhat, C., De Castro, M., \& Montibon, R. (2018). Social influence and attitude towards Teresian Core Values of grade 12 students in Sta. Teresa College [Unpublished thesis]. Sta. Teresa College, Batangas, Philippines.

Catechism of the Catholic Church. (1994). Vatican: Libreria Editrice Vaticana.

Catholic Bishops' Conference of the Philippines. (1992). Acts and decrees of the second plenary council of the Philippines. Pasay: Paulines Publishing House.

Catholic Bishops' Conference of the Philippines. (2008). Catechism for Filipino Catholics. Makati: St. Pauls.

Compendium of the catechism of the Catholic Church. (2005). Vatican: Libreria Editrice Vaticana.

Cruz, O. V. (2014). Social doctrine of the church. Manila: CBCP Communications Development Foundation, Inc.

DOCAT. (2016). San Francisco: Ignatius Press.

Flannery, A. (Ed.). (1984). Gaudium et spes. In Vatican II the conciliar and post conciliar documents (Vol. I, pp. 903-1001). Pasay: Daughters of St. Pauls.

Flannery, A. (Ed.). (1984). Gravissimum educationis. In Vatican II the conciliar and post conciliar documents (Vol. I, pp. 725-737).Pasay: Daughters of St. Paul.

Garcera, G. A. (2019). Pastoral visit exhortation on Catholic education in the Archdicoese of Lipa. Lipa: Archdiocese of Lipa.

Himes, K. (2014). 101 Questions \& answers on Catholic social teaching. Makati: St Pauls.

Ouchi, W. (1979). A conceptual framework for the design of organizational control. Management Science, 25(9), 833-848. https://doi.org/10.1287/mnsc.25.9.833

Pontifical Council for Justice and Peace. (2004). Compendium of the social doctrine of the Church. Vatican: Libreria Editrice Vaticana.

Pope Benedict XVI. (2009). Caritas in Veritate. The Holy See. Retrieved from http://www.vatican.va/content/benedict-xvi/en/encyclicals/documents/hf_ben-xvi_enc_20090629_carita s-in-veritate.html

Pope Francis. (2014). Address of Pope Francis to the participants in the World Meeting of Popular Movements.

The Holy See. Retrieved from

https://w2.vatican.va/content/francesco/en/speeches/2014/october/documents/papa-francesco_20141028 incontro-mondiale-movimenti-popolari.html.

Pope Francis. (2015). Laudato si'. The Holy See. Retrieved from http://www.vatican.va/content/francesco/en/encyclicals/documents/papa-francesco_20150524_enciclica -laudato-si.html

Pope Francis. (2019). Evangelii gaudium. The Holy See. Retrieved from http://www.vatican.va/content/francesco/en/apost_exhortations/documents/papa-francesco_esortazioneap_20131124_evangelii-gaudium.html

Pope John Paul II. (1981). Laborem Exercens. The Holy See. Retrieved from http://www.vatican.va/content/john-paul-ii/en/encyclicals/documents/hf_jp-ii_enc_14091981_laboremexercens.html

Pope John Paul II. (1987). Sollicitudo Rei Socialis. The Holy See. Retrieved from http://www.vatican.va/content/john-paul-ii/en/encyclicals/documents/hf_jp-ii_enc_30121987_sollicitud o-rei-socialis.html

Pope John Paul II. (1991). Centesimus annus. The Holy See. Retrieved from http://www.vatican.va/content/john-paul-ii/en/encyclicals/documents/hf_jp-ii_enc_01051991_centesim us-annus.html

Pope John Paul II. (1995). Evangelium Vitae. The Holy See. Retrieved from http://w2.vatican.va/content/john-paul-ii/en/encyclicals/documents/hf_jp-ii_enc_25031995_evangelium -vitae.html

Pope John XXIII. (1961). Mater et magistra. The Holy See. Retrieved from http://www.vatican.va/content/john-xxiii/en/encyclicals/documents/hf_j-xxiii_enc_15051961_mater.ht $\underline{\mathrm{ml}}$ 
Rosales, R. J. J.

Pope John XXIII. (1963). Pacem in terris. The Holy See. Retrieved from http://www.vatican.va/content/john-xxiii/en/encyclicals/documents/hf_j-xxiii_enc_11041963_pacem.ht $\underline{\mathrm{ml}}$

Sta. Teresa College. (2010). Sta. Teresa College student handbook and organizer. Bauan: Sta. Teresa College.

Villanueva, H. (2020, March 9). Interview by R. J. J. Rosales [In-person].

Villanueva, O. (2020, February 19). Interview by R. J. J. Rosales [In-person].

YOUCAT. (2010). San Francisco: Ignatius Press. 